\section{IJ§ER}

ISSN: 2149-5939
International Journal of Social Sciences and Education Research

Online, http://dergipark.gov.tr/ijsser

Volume: 3(1), 2017

\title{
An anthropological analysis popular belief on Kurdish Alevis in Turkey
}

\author{
Hiroki Wakamatsu'
}

Received Date: 03 / 09 / 2016

Accepted Date: 12 / $11 / 2016$

\begin{abstract}
Based on the Ocak (Religious oriented household), Alevi people has practiced various form of saint venerations and religious rituals in Varto sub-province in Eastern Anatolia for a long time. These saint veneration and religious rituals have a function which structures the relationship between Alevis themselves and strengthens their awareness of Alevi identity. These religious practices are divided into two categories. First one is rituals practiced by villagers and organized by Seyit (religious authority of Alevis who is descended from the Prophet's family) and his Rehber (religious guide who is appointed by Seyit) like weddings, funerals, circumcision, Nevruz (spring festival) and Cem rituals (the most important Alevi religious practice). The former is well known in the media broadcasted and published by Alevi cultural associations based on the big cities. Even non-Alevi outsiders can participate in these religious rituals. Concerning these religious practices, we can access to a lot of previous studies.
\end{abstract}

However, the latter is completely kept secret for outsiders. People practice these rituals and religious practices only within their village communities. They are different from the former practices which are practiced as a popular belief. Even villagers cannot participate in these religious practices in some case. In other word, if he or she is not a member of Ocak as a ritual group, he or she cannot participate in these rituals. At the same time, if Seyit who is descended from the Prophet family does not organize the ritual, participants cannot have Keramet (miracles).

In this paper, I introduce the case of saint veneration as a popular belief in the village communities in Varto subprovince. Then I analyze the current social situation around Alevism in Kurdish community from the view point of Cultural Anthropology.

Keywords: Kurdish Alevis, Alevism, Popular Beliefs, Saint Veneration, Cultural Anthropology

\section{Introduction}

People speaking Kurdish languages like Kurmanci or Zazaki as a mother tongue consists of $18 \%$ of total population of Turkish Republic according to CIA's investigation in $2008^{2}$. The vast majority of them is Shafi'i-Sunni Muslims. Although we cannot access to the detailed data concerning their religion, it is said that $20 \%$ of Kurdish population is Alevis. We can find the research conducted by Peter Andrews concerning ethnic groups in the Republic of Turkey titled "Ethnic Groups in the Republic of Turkey" published in Germany in 1989 (Andrews 1989).

The list of ethnic groups has a lot of problems concerning the method of classification and distribution of ethnic groups nevertheless the investigation includes a lot of citations from

${ }^{1}$ Asst. Prof. (Ph.D.) Research Institute for Alevism-Bektashism at Toros University, MERSIN/TURKEY. hiroki.wakamatsu@toros.edu.tr

$\frac{2}{2}$ See the CIA' census on the website (https://www.cia.gov/library/publications/the-worldfactbook/geos/tu.html\#People). There is no official data concerning ethnic and religious minorities in Turkish government. 
Wakamatsu, H. (2017). An anthropological analysis popular belief on Kurdish Alevis in Turkey. International Journal of Social Sciences and Education Research, 3(1), 49-57.

various disciplines about Turkish area studies. It is not only the problem derived from difficulty of definitions of their identity but it has another issues. Previous studies on the ethnographic work of Kurdish Alevis have discussed a lot of controversial issues on the definition of their identity for a long time. Readers' understanding is very confused when they read these previous studies because they find a lot of contradictions within the various opinions.

A lot of researchers have demonstrated various ethnographic data concerning Kurdish Alevis in Turkey who consist of a sizable proportion of Eastern Anatolia especially in Tunceli, Muş, Erzincan, Elazığ, Bingöl and Malatya provinces (at the same time they live in the big cities in Turkey and migrant communities in Western Europe) however, they are confronted with the difficulty to write ethnography on Kurdish Alevis. This is the reflection of complicated situation around their religious, linguistic and historical background.

On the one hand, their existence has been an attractive theme for almost of all ethnographic researchers for a long time. Because they use Turkish in their ritual practices and they have a lot of Turkish tribal names in the region although their mother tongue is Kurdish languages like Kurmanci or Zazaki. On the other hand, it is hard for both Turkish and Kurdish nationalists to accept their ambiguous and complicated identity. Even Alevis themselves cannot have specific definition of their religious or ethnic identity yet. For instance, Turkish nationalists continue to try to prove that Kurdish languages are essentially originated from the ancient Turkic language. At the same time, Kurdish nationalists exaggerate the Iranian elements within the Alevism and they assert that even Turkish Alevis accept these elements from the Iranian culture.

In this respect, I have to firstly mention that the term "Kurdish Alevis" must be scarcely used in this article although it has been uncritically explained in the previous studies. According to van Bruinessen's notion, the term "Kurdish Alevis" is shorthand for all Kurmanci- and Zaza- speaking Alevis, irrespective of whether or not they define themselves as Kurds (van Bruinessen 1997: 1-2).

At the beginning, I shall proceed to the discussion concerning the religious practices according to van Bruinessen's definition of the term "Kurdish Alevis". Then I try to reveal the complicated situation of Alevism analyzing the local rituals practiced in Alevi villages in Varto sub-province.

\section{Fortune-Telling as Saint Veneration}

In Varto sub-province, various religious rituals and the forms of saint veneration are practiced on a basic social unit called Ocak. The word Ocak literally means "household." However, it is used among the Alevi people to denote an extended family unit who claim a shared, holly descent from a particular medieval saint ${ }^{1}$. The Ocak has two aspects. One is Holy Lineage composed of Seyit dedes, and the other aspect is of a ritual group that constitutes a relationship between the master and disciple. Both aspects are referred to among the people as one Ocak. The Alevi people recognize themselves as an Alevi according to their Ocak (Wakamatsu 2015: 786).

\footnotetext{
${ }^{1}$ Detailed information about Ocak in Alevi society, see Martin van Bruinessen's work (van Bruinessen 2000: 263).
} 
Wakamatsu, H. (2017). An anthropological analysis popular belief on Kurdish Alevis in Turkey. International Journal of Social Sciences and Education Research, 3(1), 49-57.

These Ocaks have practiced the saint veneration and the religious rituals which awaken Alevi identity and the social structure and strengthen the relationship between Alevis for a long time. These religious practices are divided into two categories. On the one hand, we can observe the rituals like Cem ceremonials, formal occasions, a rite of passage like circumcision, Nevruz festival and sacrifices. These customs are carried out by Seyit ${ }^{1}$ dedes in Varto. On the other hand, there are some different religious practices from these customs. The former is the practices in which everyone can participate. At the same time these practices are influenced by city-based Alevi cultural associations through various media. The latter is secret toward outsiders and transmitted through their secret traditions.

(Case 1)

When I visit a village "A" in Varto in summer 2008, I met with a dede who is seyit. He practiced a fortune-telling. The village is situated about $5 \mathrm{Km}$ far from the main road in the mountainous area. The village had 20 households and all villagers were seyit. I heard that visitors came from neighboring provinces like Bingöl and Erzurum however, they were relatives $(A k r a b a)$ of dede or those who has an invitation from dede. At first, while visitors were invited to living room and sit down, dede practiced fortune-telling in other room. In the end of fortune-telling, I interviewed dede,

Author: What is fortune-telling? Is it related to Alevism?

Dede: I cannot tell you detailed information about fortune-telling but, when I put water

to the tub, I can imagine his or her (inner) state at that time.

Author: Can you predict my future now?

Dede: No I can not do it. Because you don't become proficient in the Way (Yol Erkânı).

Please don't misunderstand me. No one can get anything if he or she doesn't adopt the

Way. This tub is descended from our (seyit) ancestors. It is strictly prohibited to show

for outsiders.

I have interviewed concerning other things about fortune-telling from dede but I cannot explain more detailed information about it due to dede's privacy. Anyway it is very different from the ceremonies like Cem which are well-known to outsiders of Alevi communities, these practices are kept within the member of Ocak. In other word, even if he or she is a member of the village, they cannot participate in the religious practice without being on the Way as a member of Ocak. At the same time if the seyit who is descended from the Prophet family participate in the practice, no one can make a miracle.

\section{Evliyâ-e Sırrî: a Secret Saint}

Evliyâ-e Strrî means "secret saint" in Kurdish languages. In the village where I conducted my field research there were a dervish lodge called tekke named "Evliyâ-e Sirrî" and the shrine and tomb called Daqqah Yemine. This complex of tekke, shrine and tomb is supervised by a

${ }^{1}$ Seyit (Ar. Sayyid) is an honorific title; it denotes males who are accepted as descendants of the Prophet Muhammad through his grandsons, Hasan and Huseyin, the sons of the Prophet's daughter Fatima and his son-in-law. Alevis venerate as saints those seyits who are descended from Ehl-i Beyt (the Prophet's family). See the detailed information about Seyit in Kurdish Alevis researched by Wakamatsu (2013: 79). 
Wakamatsu, H. (2017). An anthropological analysis popular belief on Kurdish Alevis in Turkey. International Journal of Social Sciences and Education Research, 3(1), 49-57.

woman who is descended from seyit lineage called Bozi. In a wooden tekke we can find a tub for fortune-telling, a green mantle hung on the pillar and a holy book Qur'an. Concerning the tekke, villagers share following tradition handed down from old time (Picture 1 \& Picture 2).

Picture 1. Tekke

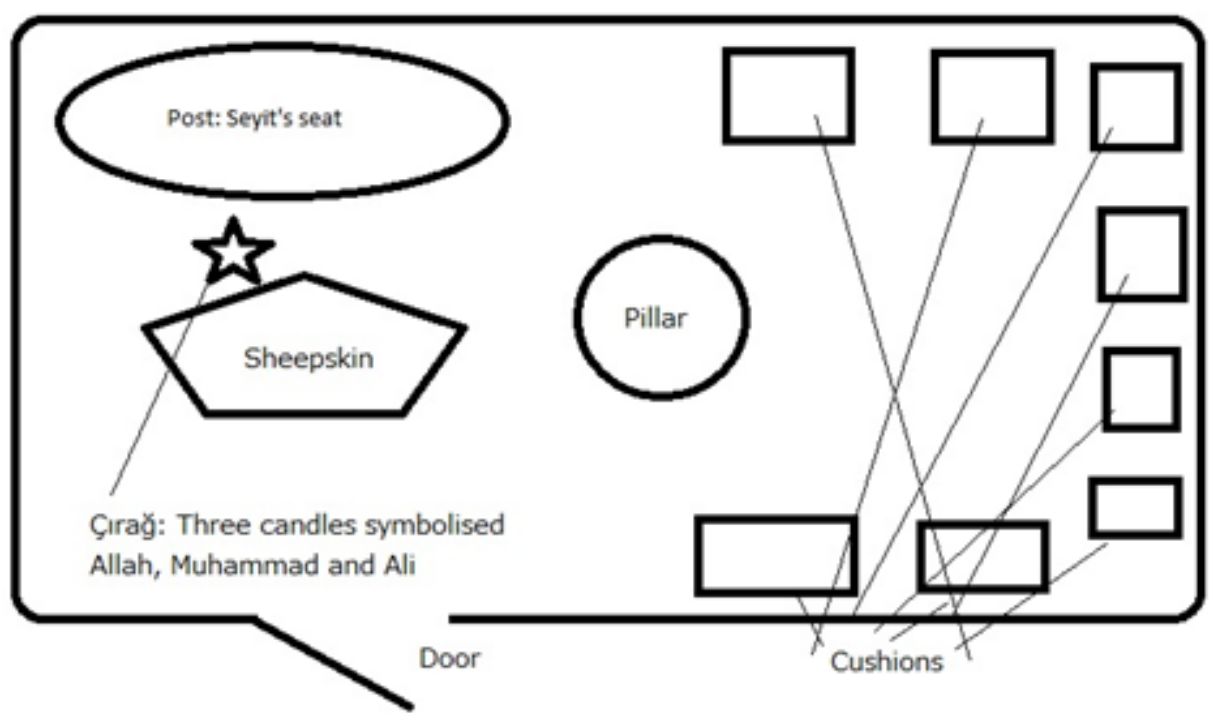

Picture 2. Tekke

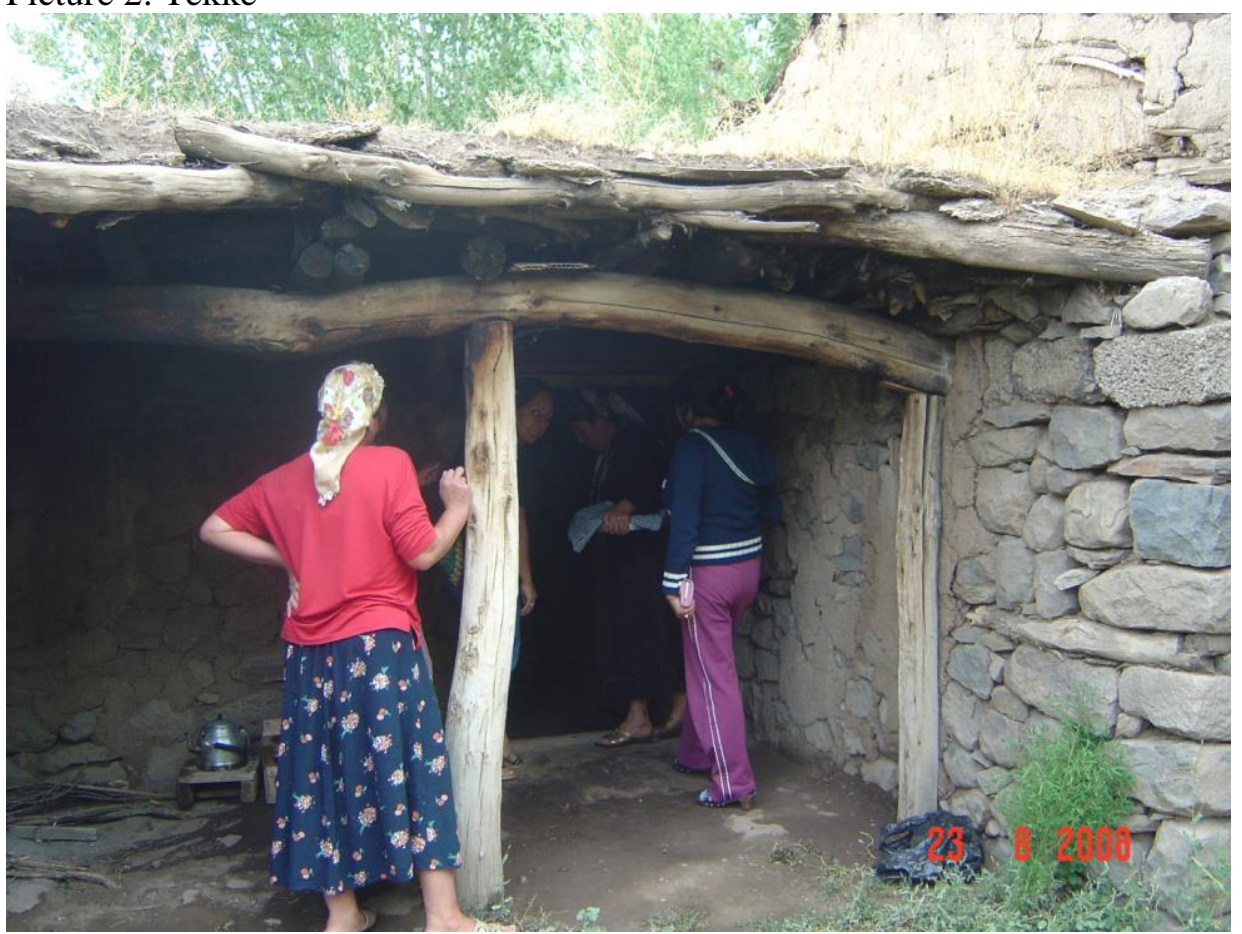

\section{(Case 2)}

When I asked a woman whose ancestors were the descendants of the Prophet about the Tomb of a village "B". She was a nephew of a dede who was seyit.

Author: Who constructed this tomb? When was it? 
Wakamatsu, H. (2017). An anthropological analysis popular belief on Kurdish Alevis in Turkey. International Journal of Social Sciences and Education Research, 3(1), 49-57.

A woman: I don't know when it was built but this tomb but this tekke belongs to Evliyâ-e Sirrî.

Author: Who is Evliyâ-e Strrî?

A woman: Long time ago, a dervish visited our village. He was a man wearing dirty clothes so villagers, I mean our ancestors, gave him meals and clean clothes. Then they lived together for forty days. They practiced Cem ceremonials and dance the $s e m a h^{l}$. Suddenly he had disappeared in fortieth day since he arrived at our village without any information. He left us a tub, a green mantle and a Qur'an. After then, in old time, dedes who are seyit have practiced fortune-telling using these Equipment up to now. Our dede said that he was the saint (Evliyâ) and he became the secret (Strr).

Author: What do you mean by the "secret"?

A woman: It means that he has been hidden. The dervish who visited our village had been hidden for a long time. This is the miracle (Keramet) from Allah, he appears here again after several thousands. He had been hidden for a long time before he visited our village. So our villagers are ready to accommodate for any time if he visits our village again. So that we built a tekke here.

Author: Now does anyone have an ability to practice fortune-telling here?

A woman: Unfortunately not here. An ability to practice (to show a person's future in the tub) is only an admitted seyit given by Allah. So not everybody can do it. Unfortunately, our dede (in the village) doesn't have the ability. His son tried to do it also but he didn't succeed although he was a seyit. But in Izmit (neighboring city of Istanbul), I have a daughter. She has the ability. When she visited our village she practiced fortune-telling for villagers.

The miracles that Evliyâ re-appears and transmits something to the people are observed in Varto region widely. What I showed in (Case 2) is generally practiced by a female saint ${ }^{2}$ rather than a male.

\section{Daqqah Yemine as a Female Saint}

Various prayers for something like "healing the illness" or "passing the examinations" are rarely made by living dedes in the Kurdish Alevi discourse. It is widely known that these religious practices are made by female saints. These female saints are called Ana contrary to that the male saints are called Dede in general. Anas are different from Dedes. Because Anas have no relations with Ocaks. Anas don't have any disciples and belong to any hierarchical organizations. At the same time they don't have capacity to practice the religious rituals like Cem ceremonials normally organized by dedes. They just practice various prayers for something like "healing the illness" or "passing the examinations" as necessary.

\footnotetext{
${ }^{1}$ Semah is one of the rituals of Sufi order in general. In Alevi-Bektashi tradition semah is practiced with music and dance.

${ }^{2}$ Concerning "female dervishes" in Alevism-Bektashism, see Bahadır's comprehensive work (Bahadır 2005: 139-164). It is thought that women descended from the Prophet Family are possessed the "Sacred" in Alevi-Bektashi society.
} 
Wakamatsu, H. (2017). An anthropological analysis popular belief on Kurdish Alevis in Turkey. International Journal of Social Sciences and Education Research, 3(1), 49-57.

For instance, the most representative case of realization of someone's earnest wishes is "passing the exams". We can observe the successful cases. According to informants in the village, one day a mother whose son cannot concentrate on his study visited Ana. Ana prayed for Allah to remove jinn from him. Then he began to succeed the tests in his school finally he passed the entrance exam for the university.

Another example is "seeking a good match". This practice is very important for Alevi communities in which the endogamy within an ocak is main tool for marriage. According to an informant who visited Ana, people depends on the "secrecy" and "the Sacred given by Allah" to her. But actually the most influential element is the human network of Ana's women relationship within Alevi society.

Speaking of "healing illness", I observed a case of a woman suffering from menstrual pain in the village "C". There is a tomb of Daqqah Yemine (Picture 3).

Picture 3. Daqqah Yemine

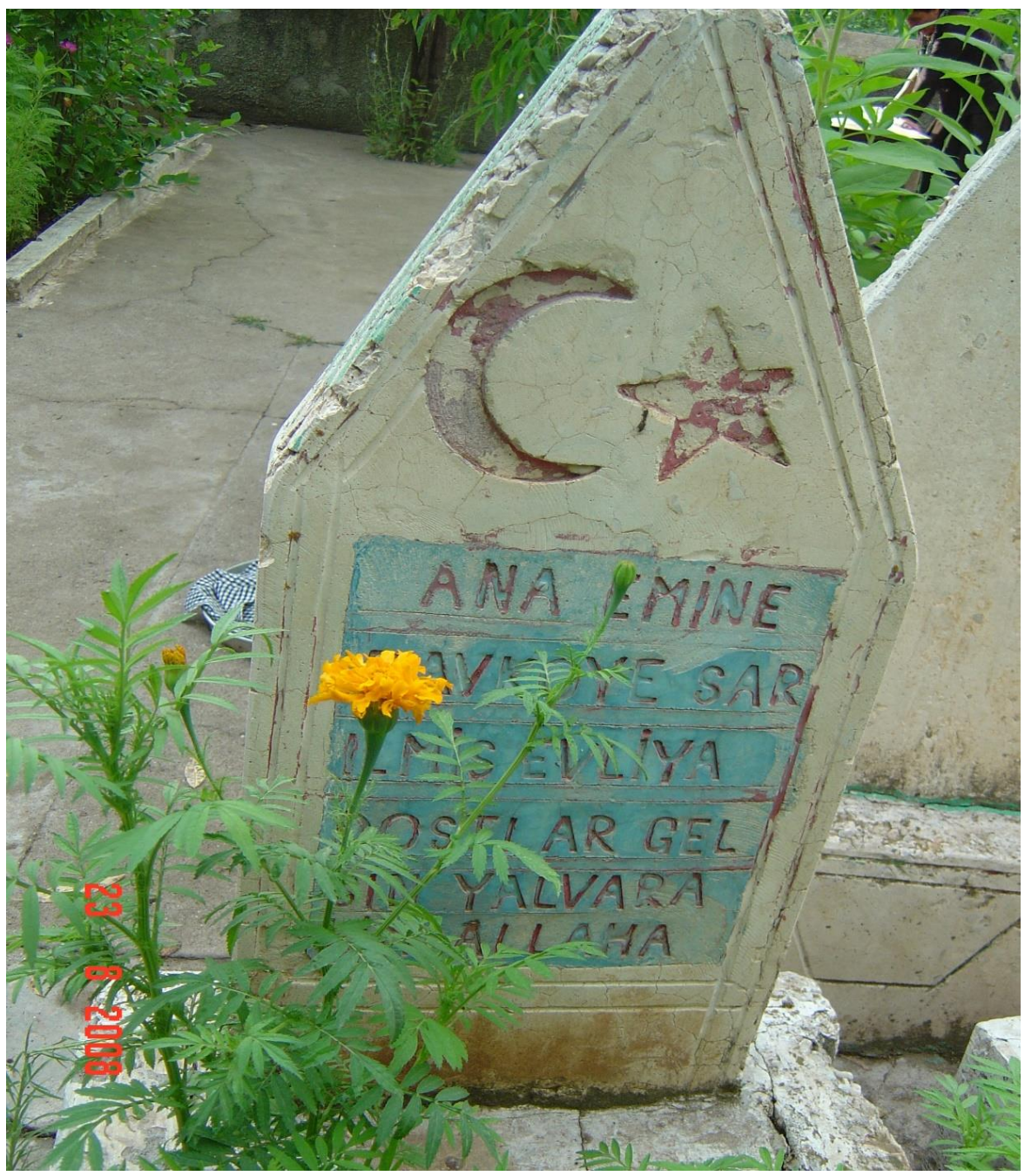

Daqqah Yemine is a local female saint dead in the first years of 1900s. It is said that she expelled Russian and Armenian armies trying to invade the village with making a miraculous power then she defended the village. When she visited Ana for healing her illness Ana gave a cup of water boiled with a small stone around the tomb of Daqqah Yemine. Then she was 
Wakamatsu, H. (2017). An anthropological analysis popular belief on Kurdish Alevis in Turkey. International Journal of Social Sciences and Education Research, 3(1), 49-57.

healed next day. People think that stones around the tomb are possessed by the "Sacredness" of Evliyâ. These miraculous narratives mean that people believe these sacredness are derived from the grace of Allah through the veneration of the holy lineage of the Prophet family.

At the same time Ana practices the fortune-telling as well. There are a lot of methods howevr, common features of fortune-telling is that Anas are possessed by the "sacredness" and have an ability to foretell the destiny. People believe that Ana gets the ability to make miracles through marriage with Seyit dede.

\section{Cem Ceremony}

Cem ceremony is constantly organized every Thursday at Tekke by dede. The term "cem" is derived from Arabic "jam". It means "collect" or "gather". Participants are belong to specific ocak and they share the pain that martyrdom of Ali, Hassan and Husain suffered in the battle of Karbala. The purpose of this ritual is to approach to be "Insan-î Kâmil (the person who reached perfection) ${ }^{1 "}$. There are some kinds of Cem ceremony such as Sultan Nevruz Cemi organized Nevruz festival, Ikrar Cemi as a rite of passage and Kırklar Cemi symbolized as Anatolian Forty Saints (Anadolu Kırk Erenleri) who are Turkic Sufis originated from Ahmet Yesevi Tradition in Khorasan.

I introduce the example of Kırklar Cemi practiced every Thursdays at the Tekke of a village. The instruction of Cem ceremony is just guided by Seyit dedes. Only descendants of the Prophet can organize the ceremony. First, dede sit down on the sheepskin called Post and participants sit down on the cushions (Picture 1). Dede then pray and cite dua for Allah. In the end of $d u a$, all participants cite "Ya Allah" putting a hand on a lip, then they cite "Ya Muhammed" putting a hand on the forehead, and finally they cite "Ya Ali" putting a hand on the chest. After this movement, one of the highest rank disciples of dede with a broom advances to the sheepskin and stands on it, say "Ya Allah, Ya Muhammed, Ya Ali". Then he sweep the sheepskin three times for purification.

After then a woman (or a girl) advances toward the sheepskin turns on three candles. Three candles called Çıră in front of the Post (Picture 1) are symbolized as Allah, Muhammad and Ali. Firstly she turns on the centre of the candle and say "Ya Allah Ya Allah Ya Allah". Then she turns on the candle on the right side and say "Ya Muhammed Ya Muhammed Ya Muhammed". Finally she turns on the left candle and say "Ya Ali Ya Ali Ya Ali". After that dede cites dua again.

Then ceremony continues with bağlama (stringed musical instrument) and with songs for the family of the Prophet and Twelver Imams. The ritual approach to the end, atmosphere of the tekke reaches its climax. Men and women of about ten people come forward in the post, they dance semah with bağlama music played by dede. Through this semah dance, people try to see the Truth (Hak) and be united to it. After the semah, the candles are turned off under the names of Allah, Muhammed and Ali by a women (or girl). At the end of the Cem, people shared the meal made from the sacrifice.

\footnotetext{
${ }^{1}$ Insân-î Kâmil is a term used as an honorific title to describe the Prophet Muhammad. It is an important in Islamic culture of the prototype of human being.
} 
Wakamatsu, H. (2017). An anthropological analysis popular belief on Kurdish Alevis in Turkey. International Journal of Social Sciences and Education Research, 3(1), 49-57.

\section{Conclusion}

Veneration for local saints Dedes and Anas is not only for living saints but also for dead saints through tomb or shrine. Tombs and shrines are always cleaned and decorated with fresh flowers by villagers. These "sacred places" are venerated by the people toward Allah and the holy family of the Prophet.

The practices like fortune-telling and realization of earnest wishes are practiced by Anas in general but religious rituals like funeral, weddings, and circumcision and Cem ceremonials are organized by Dedes. On the other hand, local saints (Dede and Ana) has an important role among the people as a medium between holy lineage (the Prophet's family) and Allah.

According to the data from my field research, we can present a hypothesis that almost of their ritual practices are derived from ancient archaic religions before the spread of Islam in Eastern Anatolia. Since they convert to Islam, their ritual practices have been gradually mixed up with Islamic elements and symbols like veneration of the Prophet family, Qur'an and green mantle. Therefore what to be actually practiced by villagers in the field must be scarcely differentiated from Islam.

At first sight, these religious practices are contradictory to Islam's creed. However, from the point of view of Sufism as a popular beliefs, one glance is enough to understand that these syncretic religious rituals are practiced as the way to be Insan-î Kâmil within the Islamic context. At the same time these religious practices have function and role to give the people something like 'an answer' to uncertainty.

Thus, the expression collected from narratives must be prudently analyzed in his or her ethnographic writings. For analysis of field data concerning religious practice and rituals, we have to put the various elements like Veneration of the saint, local knowledge, popular beliefs and expressions of narratives about their 'history' in order. Then, we can seize these ethnographic data. Finally we pay attention to the relation with worldly divine grace and the relationship between local saint and monotheism.

\section{References}

Andrews, P. A (1989). Ethnic Group in the Republic of Turkey, Wiesbaden: Dr. Reinchert Verlag.

Bahadır, İ. (2005). Alevî ve Sünnî Tekkelerinde Kadın Dervişler, İstanbul: Su Yayınları.

Dressler, M. (2013). Writing Religion: The Making of Turkish Alevi Islam, Oxford: Oxford University Press.

Hasluck, F. W. (1921). "Heterodox Tribes of Asian Minor," The Journal of the Royal Anthropological Institute of Great Britain and Ireland, vol.51, 310-342.

Shankland, D. (2003). Alevis in Turkey: The Emergence of a Secular Islamic Tradition, London: Routledge Curzon.

Sykes, M. (1915). The Caliphs Last Heritage: A Short History of Ottoman Empire, London: MacMillan. van Bruinessen, Martin 1992 (1978). Agha, Shaikh and State: The Social and Political Structures in Kurdistan, Zab Books.

1997. "Aslını İnkâr Eden Harâmzâdedir!: The Debate on the Ethnic Identity of the Kurdish Alevis," Krisztina Kehl-Bodrogi (ed.), Syncretistic Religious Communities in the Near East, Leiden: Brill, 1-23.

-2000. Mollahs, Sufis and Heretics: The Role of Religion in Kurdish Society. Collected Articles, Istanbul: ISIS. 
Wakamatsu, H. (2017). An anthropological analysis popular belief on Kurdish Alevis in Turkey. International Journal of Social Sciences and Education Research, 3(1), 49-57.

Wakamatsu, H. (2013). "Veneration of the Sacred or Regeneration of the Religious: An Analysis of Saints and the Popular Beliefs of Kurdish Alevis," Journal of Sophia Asian Studies, No. 31, 69-84. (2015). "Transmitting the Tradition: An Analysis on Master-Disciple Relationship in Alevi Community of Turkey," International Journal of Social Sciences and Education Research, 1 (3), 772-789. 